\title{
Differential Effects of Olanzapine and Haloperidol on MK-801-induced Memory Impairment in Mice
}

\author{
Jae Chun Song ${ }^{1}$, Mi Kyoung Seo ${ }^{1}$, Sung Woo Park ${ }^{1,2}$, Jung Goo Lee ${ }^{1,2,3}$, Young Hoon Kim ${ }^{1,2,3}$ \\ ${ }^{1}$ Paik Institute for Clinical Research, ${ }^{2}$ Department of Health Science and Technology, Graduate School, Inje University, ${ }^{3}$ Department of \\ Psychiatry, Inje University Haeundae Paik Hospital, Inje University School of Medicine, Busan, Korea
}

\begin{abstract}
Objective: We investigated the differential effects of the antipsychotic drugs olanzapine and haloperidol on MK-801-induced memory impairment and neurogenesis in mice.

Methods: MK-801 $(0.1 \mathrm{mg} / \mathrm{kg})$ was administered 20 minutes prior to behavioral testing over 9 days. Beginning on the sixth day of MK-801 treatment, either olanzapine $(0.05 \mathrm{mg} / \mathrm{kg})$ or haloperidol $(0.05 \mathrm{mg} / \mathrm{kg})$ was administered 40 minutes prior to MK-801 for the final 4 days. Spatial memory performance was measured using a Morris water maze (MWM) test for 9 days (four trials/day). Immunohistochemistry with bromodeoxyuridine (BrdU) was used to identify newborn cells labeled in tissue sections from the dentate gyrus of the hippocampus.

Results: MK-801 administration over 9 days significantly impaired memory performance in the MWM test compared to untreated controls $(p<0.05)$ and these deficits were blocked by treatment with olanzapine $(p<0.05)$ but not haloperidol. The administration of MK-801 also resulted in a decrease in the number of BrdU-labeled cells in the dentate gyrus (28.6\%; $p<0.01)$, which was prevented by treatment with olanzapine $(p<0.05)$ but not haloperidol.

Conclusion: These results suggest that olanzapine has a protective effect against cognitive impairments induced by MK-801 in mice via the stimulating effects of neurogenesis.
\end{abstract}

KEY WORDS: Olanzapine; Haloperidol; Memory; NMDA antagonist; Neurogenesis.

\section{INTRODUCTION}

Schizophrenia is a severe chronic illness with a debilitating course in which patients suffer from multiple episodes. In the aftermath of schizophrenic episodes, the impairment of social and occupational function may continue. ${ }^{1)}$ Schizophrenia consists of several symptom domains that shows different response to treatment. ${ }^{2)}$ Among symptom domains of schizophrenia, cognitive symptoms may be persisting after successful treatment of positive symptoms and may affect social and occupation functions of the patients of schizophrenia. ${ }^{2)}$

Received: December 29, 2015 / Revised: February 16, 2016

Accepted: February 17, 2016

Address for correspondence: Jung Goo Lee, MD, PhD

Department of Psychiatry, Inje University Haeundae Paik Hospital,

875 Haeun-daero, Haeundae-gu, Busan 48108, Korea

Tel: +82-51-890-6749, Fax: +82-51-894-6709

E-mail: iybihwc@naver.com

Young Hoon Kim, MD, PhD

Department of Psychiatry, Inje University Haeundae Paik Hospital,

875 Haeun-daero, Haeundae-gu, Busan 48108, Korea

Tel: +82-51-890-6749, Fax: +82-51-894-6709

E-mail: neuro109@hanmail.net
First generation antipsychotic (FGA) drugs, such as haloperidol and chlorpromazine, have been used to treat schizophrenia and show efficacy for relieving the psychotic symptoms of schizophrenia. ${ }^{3)}$ However, FGAs failed to show improvement on cognitive dysfunction. ${ }^{4)}$ Some second generation antipsychotic (SGA) drugs, such as olanzapine and quetiapine, are not only efficacious for the treatment of delusions and hallucinations but also have positive effects on mood and cognitive symptoms. ${ }^{4,5)}$ Moreover, some SGAs has been known to have possible neuroprotective effects and these effects might be related with cognitive functions. ${ }^{6)}$ As schizophrenia progresses the volume of the cerebral cortex decreases. ${ }^{7)}$ For example, Thompson et al. ${ }^{7)}$ found a decreased cerebral cortical volume in early-onset first-episode schizophrenia patients after 2 years of olanzapine or haloperidol treatment. A decreased brain volume was associated with haloperidol but not olanzapine. ${ }^{6}$

Based on such clinical findings, it appears that olanzapine may have neuroprotective effects relative to cognitive function. In addition, a growing body of experimental evidence from in vivo and in vitro studies has demon-

() This is an Open-Access article distributed under the terms of the Creative Commons Attribution Non-Commercial License (http://creativecommons.org/licenses/by-nc/4.0) which permits unrestricted non-commercial use, distribution, and reproduction in any medium, provided the original work is properly cited. 
strated that some SGAs have neuroprotective effects whereas FGAs, such as haloperidol, do not. In fact, FGAs may even cause oxidative stress, which can result in apoptotic cell death. ${ }^{8-15)}$ As mentioned above, based on research that has investigated long-term treatments for schizophrenia and on opinions from brain mapping, it can be presumed that SGAs have neuroprotective effects.

MK-801 is a noncompetitive N-methyl-D-aspartate (NMDA) receptor antagonist and repeated injection of MK-801 has been known to induce schizophrenia-like behavioral alternations and metabolic changed in animal brains. ${ }^{16-20)}$ Repeated MK-801 injections also impairs learning and memory functions or rat $^{21-23)}$ and reduces neurogenesis and brain-derived neurotrophic factor (BDNF) in the rat hippocampus. ${ }^{24,25)}$ In the present study, we used repeated MK-801 injections for making impaired cognitive model and evaluated whether the differential effects of the antipsychotic drugs olanzapine and haloperidol. Morris water maze (MWM) test was used for the evaluation of cognitive functions. In addition, we evaluate the effects of these drugs on hippocampal neurogenesis with immunohistochemistry.

\section{METHODS}

\section{Animals}

All animal manipulations were performed in accordance with the animal care guidelines of the US National Institutes of Health (NIH publication no. 23-85, revised 1996) and the Korean Academy of Medical Science. All experiments involving animals were approved by the Committee for Animal Experimentation and the Institutional Animal Laboratory Review Board of Inje Medical College (approval No. 2009-009). This study included adult male C57BL/6J mice (Orient Bio, Seongnam, Korea) weighing 20-22 g. Animals were housed (five per cage) with food and water freely accessible and main- tained at $21^{\circ} \mathrm{C}$ in a $12: 12$ light:dark cycle. The mice were used for the behavioral experiments after they had adapted to laboratory conditions for 7 days and were randomly divided into four groups of five mice each. The first (control) and second (MK-801) groups received saline as a vehicle and MK-801 (0.1 mg/kg, intraperitoneal [i.p.]). The mice in the third (MK-801 + olanzapine) and fourth (MK-801 + haloperidol) groups received olanzapine $(0.05 \mathrm{mg} / \mathrm{kg}$, i.p. $)$ and haloperidol $(0.05 \mathrm{mg} / \mathrm{kg}$, i.p. $)$, respectively.

\section{Drug Treatment}

This study utilized MK-801 and haloperidol (Sigma, St. Louis, MO, USA) and olanzapine (Eli Lilly Research Laboratories, Indianapolis, IN, USA). Olanzapine and haloperidol were dissolved in $0.3 \mathrm{M} \mathrm{HCl}$ in saline after which the $\mathrm{pH}$ was adjusted to 5.5-6.0 with sodium hydroxide. ${ }^{26)}$ MK-801 was dissolved in saline. The drugs dose was selected based on a Kant et al. ${ }^{27)}$ and previous study from our lab (data not shown). In the water maze experiment, MK-801 $(0.1 \mathrm{mg} / \mathrm{kg})$ was administered $20 \mathrm{mi}$ nutes prior to behavioral testing over 9 days. ${ }^{28)}$ Beginning on the sixth day of MK-801 treatment, either olanzapine $(0.05 \mathrm{mg} / \mathrm{kg})$ or haloperidol $(0.05 \mathrm{mg} / \mathrm{kg})$ was given 60 minutes prior to behavioral testing, which was 40 minutes prior to MK-801 treatment, for 4 days (Fig. 1).

\section{Morris Water Maze Test}

The MWM test is a behavioral task that is a commonly used model for learning and memory research. A circular swimming pool measuring $150 \mathrm{~cm}$ in diameter and $50 \mathrm{~cm}$ in height was filled to a depth of $35 \mathrm{~cm}$ with water that was kept at $26 \pm 2^{\circ} \mathrm{C}$ and clouded with a colored white dye (Tempera; Fine Art Supplies, Auckland, New Zealand) to make the platform invisible. Four equally spaced points around the edge of the pool were designated east (E), south (S), west (W), and north (N). An escape platform (12 cm in diameter) was set $1 \mathrm{~cm}$ below the surface of the



Fig. 1. Schematic diagram of experiment schedule. MK-801 (0.1 mg/kg) was administered 20 minutes prior to behavioral testing for a total of 9 days. Following 6 days of treatment with MK-801, either olanzapine $(0.05 \mathrm{mg} / \mathrm{kg})$ or haloperidol $(0.05 \mathrm{mg} / \mathrm{kg})$ was administered $40 \mathrm{minutes}$ prior to administration of MK-801 for a total of 4 days. Spatial memory performance was measured in a Morris water maze test over 9 days (4 trials/day). 
water and placed in a constant position in the middle of the SE quadrant. The swim paths of the mice were automatically recorded using the HVS image-tracking system (HVS Image, Hampton, UK). ${ }^{29)}$ Each subject performed the task four times daily in intervals of 1 minute and trials began by placing a mouse by hand into the water facing the wall of the circular pool at the $\mathrm{E}, \mathrm{S}, \mathrm{W}$, or $\mathrm{N}$ points around the edge of the pool. Mice were allowed to swim to the hidden platform and the escape latency was recorded. After reaching the platform, the mice were allowed to stay on the platform for 20 seconds and then gently moved to a drying cage where they stayed for 10 minutes before being returned to the home cage. If the mouse failed to find the platform within 1 minute, it was gently placed onto the platform where it was allowed to stay for 1 minute.

\section{Bromodeoxyuridine (BrdU) Labeling}

BrdU was prepared in saline at a dilution of $20 \mathrm{mg} / \mathrm{ml}$ BrdU. Solutions were dissolved by sonication and prepared on the same day they were used. To examine cell proliferation, BrdU was injected $(200 \mathrm{mg} / \mathrm{kg}$, i.p.) on the last day of MWM testing, 1 day before death. At 24 hours after injection, the subjects were deeply anesthetized and sacrificed with pentobarbital $(50 \mathrm{mg} / \mathrm{kg}$, i.p.) and then transcardially perfused with ice-cold phosphate-buffered saline (PBS, pH 7.4) followed by ice-cold 4\% paraformaldehyde (Sigma) in PBS. Following perfusion, all brains were post-fixed in paraformaldehyde until use. Serial sections of $50 \mu \mathrm{m}$ were cut through the entire hippocampus $^{30)}$ on a vibratome (Series 1000 Sectioning System; Technical Products International, O'Fallon, MO, USA) and stored in a 24 -well plate with $4 \%$ formalin.

\section{Immunohistochemistry}

Free-floating sections were used to determine BrdU labeling. DNA was denatured by incubating the samples for 2 hours in $50 \%$ formamide/2X SSC at $65^{\circ} \mathrm{C}$ followed by several $2 \mathrm{X}$ SSC rinses. Then the sections were incubated for 30 minutes in $3 \mathrm{M} \mathrm{HCl}$ at $37^{\circ} \mathrm{C}$ and washed for 10 minutes in $0.1 \mathrm{M}$ boric acid $(\mathrm{pH} 8.5)$ after being incubated in $0.3 \%$ TritonX-100 for 15 minutes. After the sections were washed with PBS and incubated for $30 \mathrm{mi}-$ nutes, proteinase K ( $1 \mu \mathrm{g} / \mathrm{ml}$; Amresco, Solon, OH, USA) was added at $37^{\circ} \mathrm{C}$. After rinsing with PBS, sections were incubated for 10 minutes in $3 \% \mathrm{H}_{2} \mathrm{O}_{2}$ to eliminate endogenous peroxidases. Then they were placed in a blocking serum (Novostain Super ABC kit; Novocastra, Newcastle, UK) in PBS for 1 hour and incubated overnight with anti-mouse BrdU (1:200; Dako, Glostrup, Denmark) at $4^{\circ} \mathrm{C}$.
The following day, the sections were incubated for $90 \mathrm{mi}-$ nutes with a secondary antibody (biotinylated horse anti-mouse; Vector Laboratories, Burlingame, CA, USA) followed by 1 hour in an avidin-biotin enzyme complex reagent. After washing in PBS, the reaction product was detected using diaminobenzidine (peroxidase substrate kit, SK-4100 DAB; Vector Laboratories). Sections were mounted onto gelatin-coated slides, dehydrated with a series of alcohol rinses $(70 \%, 90 \%$, and $100 \%)$, and incubated for 5 minutes in xylene after being coverslipped with Permount (SP15-500, Fisher Scientific, Waltham, MA, USA).

\section{Statistical Analysis}

For BrdU-labeled cells, counted sections spaced at least $160 \mu \mathrm{m}$ apart were subjected to a blind densitometric analysis via a digital image analysis system (Image-Pro Plus version 3.0; Media Cybernetics, Silver Spring, MD, USA). Sections were divided between the anterior, middle, and posterior thirds of the hippocampus (Bregma: -2.3 to $-4.0 \mathrm{~mm}$ ) and analyzed for BrdU immunostaining in an area encompassing the entire granule cell layer extending approximately two cell layer widths deep into the hilus (subgranular proliferative zone). Lighter-immunostained cells and small BrdU-labeled nuclei at the hilar border were excluded from the analysis. ${ }^{31)}$ The data are presented as mean \pm standard error of mean for three independent experiments, for each of which a oneway analysis of variance (ANOVA) was performed. Post hoc comparisons using Scheffe's and Duncan's test were performed and values were deemed significant at $p<0.05$.

\section{RESULTS}

\section{Effects of Olanzapine and Haloperidol in MK-801- injected Mice in the MWM Test}

\section{Escape latency}

The escape latency (time to reach the platform) in the MWM test for the four groups is presented in Table 1 . Compared to the control group, there was an increased escape latency observed in MK-801-treated mice beginning on day 6 and continuing through day 9 ( $p<0.05$, Fig. 2A). The escape latency on days 7 and 8 were decreased in olanzapine-treated mice $(0.05 \mathrm{mg} / \mathrm{kg})$ compared to MK-801-treated mice and this difference was significant on day 8 ( $p<0.05$, Fig. 2A). Haloperidol $(0.05 \mathrm{mg} / \mathrm{kg})$ treatment did not affect the escape latency of MK-801treated mice (Fig. 2A). 


\section{Swimming distance}

Compared to the control group, an increase in swimming distance was observed in MK-801-treated mice be-

Table 1. Changes in the escape latency of C57BL/6 mice (second)

\begin{tabular}{ccccc}
\hline & & \multicolumn{3}{c}{ MK-801 } \\
\cline { 3 - 5 } Day & Control & - & Olanzapine & Haloperidol \\
\cline { 3 - 5 } & & $60.0 \pm 0.0$ & $60.0 \pm 0.0$ & $57.1 \pm 2.9$ \\
2 & $36.1 \pm 7.3$ & $56.3 \pm 2.5$ & $57.8 \pm 2.2$ & $47.4 \pm 6.7$ \\
3 & $34.0 \pm 5.5$ & $56.1 \pm 3.9$ & $52.4 \pm 3.4$ & $51.0 \pm 8.6$ \\
4 & $37.0 \pm 6.3$ & $59.4 \pm 0.6$ & $46.4 \pm 1.2$ & $54.5 \pm 3.4$ \\
5 & $29.2 \pm 5.6$ & $51.8 \pm 3.2$ & $45.6 \pm 3.0$ & $37.0 \pm 7.6$ \\
6 & $18.3 \pm 3.0$ & $56.7 \pm 2.3^{*}$ & $46.7 \pm 4.4$ & $41.1 \pm 8.3$ \\
7 & $18.9 \pm 5.2$ & $50.1 \pm 5.9^{*}$ & $32.3 \pm 5.8$ & $40.3 \pm 10.1$ \\
8 & $28.8 \pm 6.3$ & $57.9 \pm 2.0^{*}$ & $24.7 \pm 5.6^{\dagger}$ & $45.3 \pm 4.3$ \\
9 & $20.0 \pm 3.7$ & $46.6 \pm 6.4^{*}$ & $30.8 \pm 7.0$ & $40.2 \pm 4.3$ \\
\hline
\end{tabular}

Values are presented as mean \pm standard error of mean for six animals per group.

In each trial, mice were placed in the pool at a single starting position and allowed to swim freely until they found the platform. The time required to escape onto the hidden platform was recorded.

${ }^{*} p<0.05$ vs. control group, ${ }^{\dagger} p<0.05$ vs. MK-801-treated group.

\section{A}



C

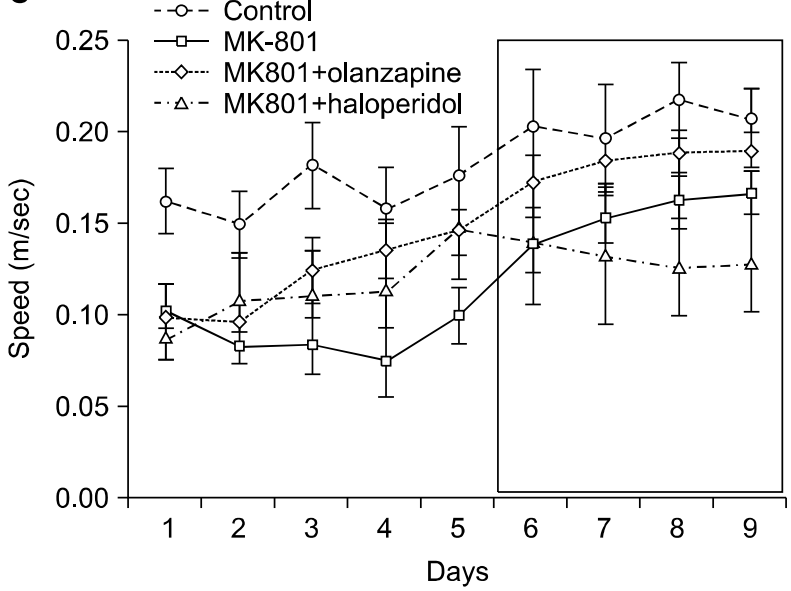

ginning on day 4 and continuing through day 9 and this difference was significant on days 6 and 7 ( $p<0.05$, Fig. $2 \mathrm{~B})$. There were no differences of swimming distance between MK-801 treated-group and MK-801 plus olanzapine treated-group (Fig. 2B). However, compared with in MK-801-treated group, haloperidol treated group resulted in a significant decrease in swimming distance was observed in haloperidol-treated group in day 6 and 7 ( $p<0.05$, Fig. 2B).

\section{Swimming speed}

Haloperidol decreased swimming speed but this did not reach statistical significance (Fig. 2C).

\section{Effects of Olanzapine and Haloperidol on Hippocampal Neurogenesis Following MK-801 Administration}

\section{Hippocampal neurogenesis}

Images of BrdU-labeled cells for all four groups are shown in Fig. 3A. The total proportions of BrdU-labeled cells from the control, MK-801, olanzapine + MK-801, and

\section{B}

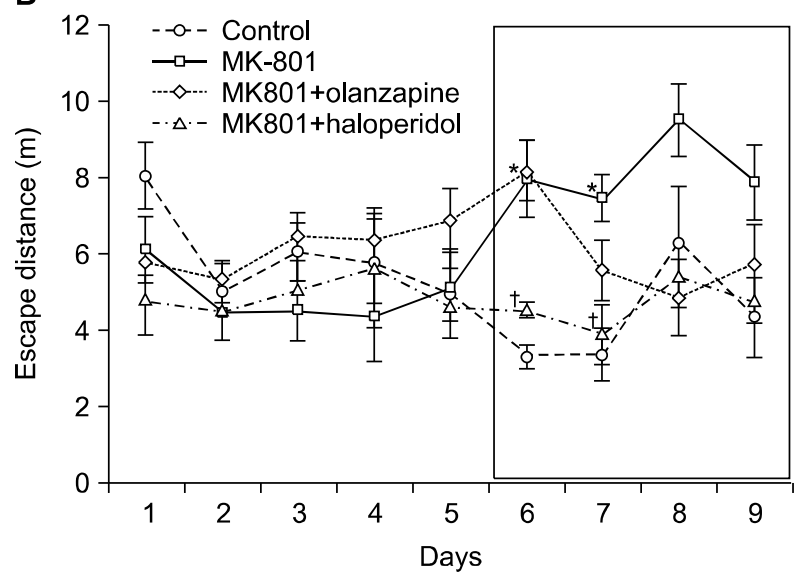

Fig. 2. The effects of olanzapine and haloperidol on MK-801-induced memory impairment in the Morris water maze test. Escape latency (A), escape distance (B), and speed (C) were determined over 9 days (4 trials/day) after training. MK-801 (0.1 mg/kg) was administered 20 minutes prior to behavioral testing over 9 days. Following 6 days of treatment with MK-801, either olanzapine $(0.05 \mathrm{mg} / \mathrm{kg})$ or haloperidol $(0.05 \mathrm{mg} / \mathrm{kg})$ was administered 40 minutes prior to treatment with MK-801 for a total of 4 days. The black box represents the period of treatment with haloperidol or olanzapine. All values are mean \pm standard error of mean for five animals per group. ${ }^{*} p<0.05$ vs. control group, ${ }^{\dagger} p<0.05$ vs. MK-801-treated group. 
A

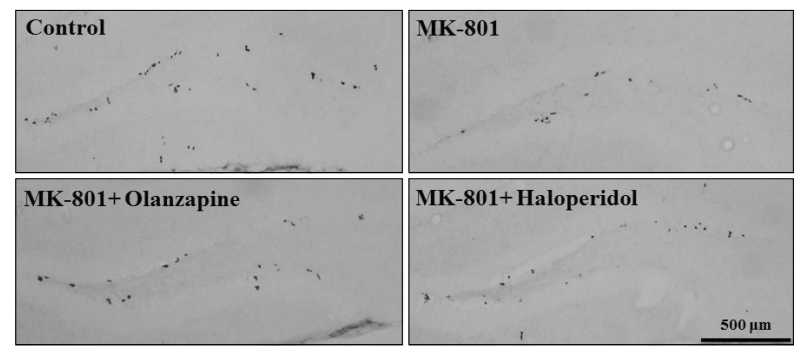

B

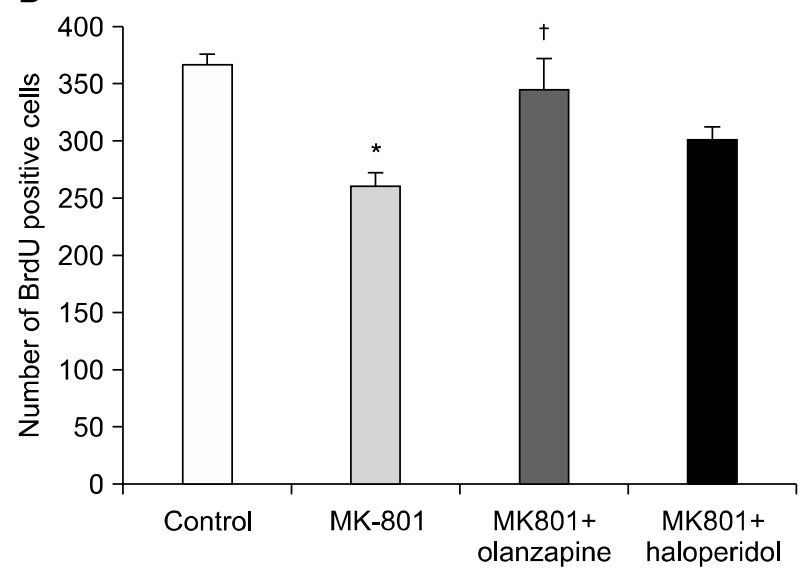

Fig. 3. Effects of olanzapine and haloperidol on neurogenesis in the dentate gyrus of the hippocampus after the Morris water maze test. (A) Representative photomicrographs of control, MK-801, MK-801+olanzapine, and MK-801+haloperidol groups. The majority of bromodeoxyuridine (BrdU)-labeled cells are located in the subgranular zone of the hippocampal dentate gyrus in the region between the granule cell layer and hilus. (B) Effects of olanzapine and haloperidol on the MK-801-induced decrease in the number of BrdU-labeled cells. Data are expressed as mean \pm standard error of mean; ${ }^{*} p<0.01$ vs. control group, ${ }^{\dagger} p$ $<0.05$ vs. MK-801-treated group.

haloperidol+MK-801 groups were $364.8 \pm 11.08$ cells, $260.5 \pm 12.51$ cells, $345.5 \pm 26.41$ cells, and $301.1 \pm 9.11$ cells, respectively. MK-801 resulted in a significant $28.6 \%$ decrease in the number of BrdU-labeled cells relative to the control group ( $p<0.01$, Fig. 3B). Olanzapine induced a significant increase in the number of BrdU-labeled cells compared to the MK-801 group ( $p<0.05$, Fig. $3 \mathrm{~B})$ but haloperidol did not influence the number of BrdU-labeled cells in MK-801-treated mice.

\section{DISCUSSION}

The administration of antipsychotic drugs in conjunction with MK-801 over 4 days resulted in changes in memory function and neurogenesis according to the class of antipsychotic drug. Treatment with MK-801 impaired memory function in $\mathrm{C} 57 \mathrm{BL} / 6 \mathrm{~J}$ mice but this deficit was restored by olanzapine, which also facilitated neurogenesis.

Olanzapine, but not haloperidol, reversed memory impairments in MK-801-treated mice during performance in the MWM test. A previous study ${ }^{32)}$ reported relatively long-term differential effects of SGAs and haloperidol on cognitive function in Wistar rats, where relative to olanzapine, haloperidol significantly impaired learning performance and decreased choline acetyltransferase (ChAT) in the cortex and hippocampus; in contrast, olanzapine treatment increased ChAT activity. Haloperidol impairs learning performance compared to risperidone and clozapine, which also reduce ChAT. ${ }^{33)}$ Moreover, haloperidol reduces levels of nerve growth factor in the rat brain and impairs performance in the MWM test. ${ }^{34)}$ These findings suggest that different types of antipsychotic drugs may have different effects on memory function and neurogenesis in the brain. In this study, the acute effects of antipsychotic drugs on memory function and neurogenesis were investigated. Pretreatment with MK-801 induced impairments in spatial learning performance in the MWM test. Five days of MK-801 treatment induced cognitive impairments and 9 days of MK-801 treatment reduced neurogenesis in the rat hippocampus. Mandillo et al. ${ }^{35)}$ reported that 5 days of repeated MK-801 administration selectively and differentially impairs the ability of mice to discriminate a spatial change. Zemanova et al. ${ }^{36)}$ observed that visuospatial working memory is impaired in an animal model of schizophrenia induced by acute treatment with MK-801. MK-801 is known to induce neurotoxicity. For example, Willis and Ray ${ }^{37)}$ found that MK-801 results in cortical neurotoxicity in the rat brain. Likewise, the repeated administration of MK-801 results in a decreased number of BrdU-labeled cells in the dentate gyrus of mice. ${ }^{38)}$

In contrast, Storozheva et al. ${ }^{39)}$ found that the administration of MK-801 (50 $\mu \mathrm{g} / \mathrm{kg}) 24$ hours after the completion of training in the MWM test improves the resistance of spatial memory to spontaneous extinction. Similarly, treatment with a non-competitive NMDA receptor antagonist such as ketamine or MK-801 can increase neural stem cell proliferation in the hippocampal dentate gyrus. ${ }^{40,41)}$ Ketamine in particular alters the proliferation and increases the neuronal differentiation of neural stem progenitor cells in the rat neocortex. ${ }^{42)}$ Li et $a l .{ }^{43)}$ observed that ketamine increased mTOR signaling activity and increased synaptogenesis and decreased immobility in mice. That is, glutamatergic enhancement may be effect neural plasticity. Although these findings were not confirmed by our results, these differences may be at- 
tributed to the duration and dosage of NMDA receptor antagonist treatment.

Several studies have demonstrated that SGAs such as olanzapine, clozapine, and quetiapine increase levels of neurogenesis in different regions of the rat brain. ${ }^{44-47)}$ More specifically, phencyclidine attenuates neurogenesis in the dentate gyrus of the hippocampus but this can be blocked by clozapine. ${ }^{35)}$ Similarly, the present results show that olanzapine blocks the attenuation of neurogenesis by MK-801. In previous studies from our lab, olanzapine significantly attenuated serum withdrawal-induced cell loss ${ }^{48)}$ and increased BDNF gene transcription via an enhancement of CREB-mediated transcription through the PKA, PI3K, PKC, and CaMKII signaling pathways. ${ }^{49)}$ Moreover, the chronic administration of olanzapine significantly attenuates the decreased expression of these proteins in the rat hippocampus following immobilization stress. ${ }^{50)}$ Thus, it is proposed here that olanzapine may have has neuroprotective effects and it is likely that this increase in neurogenesis is related to the therapeutic effects of antipsychotic drugs in patients with schizophrenia.

MK-801-induced memory impairment in the MWM test may be improved by treatment with olanzapine, but not haloperidol. In addition, possible olanzapine-induced neurogenesis was observed, suggesting that olanzapine may possess the ability to alter cognitive function in patients with schizophrenia.

\section{- Acknowledgments}

This research was supported by Basic Science Research Program through the National Research Foundation of Korea (NRF) funded by the Ministry of Education (No. 2015R1D1A3A01016360 to JG Lee).

\section{REFERENCES}

1. Stahl SM. Psychosis and schizophrenia. In: Grady MM, editor. Stahl's essential psychopharmacology. 3rd ed. New York:Cambridge University Press;2008. p.247-253.

2. Citrome L. Unmet needs in the treatment of schizophrenia: new targets to help different symptom domains. J Clin Psychiatry 2014;75 Suppl 1:21-26.

3. Yatham LN, Goldstein JM, Vieta E, Bowden CL, Grunze $\mathrm{H}$, Post RM, et al. Atypical antipsychotics in bipolar depression: potential mechanisms of action. J Clin Psychiatry 2005;66 Suppl 5:40-48.

4. Keefe RS, Bilder RM, Davis SM, Harvey PD, Palmer BW, Gold JM, et al. Neurocognitive effects of antipsychotic medications in patients with chronic schizophrenia in the CATIE Trial. Arch Gen Psychiatry 2007;64:633-647.

5. Meltzer HY. Atypical antipsychotic drugs. In: Bloom FE, Kupfer DJ, editors. Psychopharmacology. 4th ed. New York: Raven Press;1995. p.1277-1286.

6. Lieberman JA, Tollefson GD, Charles C, Zipursky R, Sharma T, Kahn RS, et al; HGDH Study Group. Antipsychotic drug effects on brain morphology in first-episode psychosis. Arch Gen Psychiatry 2005;62:361-370.

7. Thompson PM, Vidal C, Giedd JN, Gochman P, Blumenthal $\mathrm{J}$, Nicolson $\mathrm{R}$, et al. Mapping adolescent brain change reveals dynamic wave of accelerated gray matter loss in very early-onset schizophrenia. Proc Natl Acad Sci U S A 2001;98:11650-11655.

8. Bai O, Wei Z, Lu W, Bowen R, Keegan D, Li XM. Protective effects of atypical antipsychotic drugs on PC12 cells after serum withdrawal. J Neurosci Res 2002;69: 278-283.

9. Luo C, Xu H, Li XM. Quetiapine reverses the suppression of hippocampal neurogenesis caused by repeated restraint stress. Brain Res 2005;1063:32-39.

10. Wang HD, Dunnavant FD, Jarman T, Deutch AY. Effects of antipsychotic drugs on neurogenesis in the forebrain of the adult rat. Neuropsychopharmacology 2004;29:1230-1238.

11. Wei Z, Bai O, Richardson JS, Mousseau DD, Li XM. Olanzapine protects PC12 cells from oxidative stress induced by hydrogen peroxide. J Neurosci Res 2003;73: 364-368.

12. Wei Z, Mousseau DD, Richardson JS, Dyck LE, Li XM. Atypical antipsychotics attenuate neurotoxicity of betaamyloid(25-35) by modulating Bax and Bcl-X(l/s) expression and localization. J Neurosci Res 2003;74:942-947.

13. Yulug B, Yildiz A, Hüdaoglu O, Kilic E, Cam E, Schäbitz WR. Olanzapine attenuates brain damage after focal cerebral ischemia in vivo. Brain Res Bull 2006;71:296-300.

14. Behl C, Rupprecht R, Skutella T, Holsboer F. Haloperidolinduced cell death--mechanism and protection with vitamin $E$ in vitro. Neuroreport 1995; 7:360-364.

15. Noh JS, Kang HJ, Kim EY, Sohn S, Chung YK, Kim SU, et al. Haloperidol-induced neuronal apoptosis: role of $p 38$ and c-Jun-NH(2)-terminal protein kinase. $J$ Neurochem 2000; $75: 2327-2334$.

16. Ogren SO, Goldstein M. Phencyclidine- and dizocilpineinduced hyperlocomotion are differentially mediated. Neuropsychopharmacology 1994;11:167-177.

17. Corbett R, Camacho F, Woods AT, Kerman LL, Fishkin RJ, Brooks $\mathrm{K}$, et al. Antipsychotic agents antagonize non-competitive $N$-methyl-D-aspartate antagonist-induced behaviors. Psychopharmacology (Berl) 1995;120:67-74.

18. Moghaddam B, Jackson ME. Glutamatergic animal models of schizophrenia. Ann N Y Acad Sci 2003;1003:131-137.

19. Javitt DC, Zukin SR. Recent advances in the phencyclidine model of schizophrenia. Am J Psychiatry 1991;148:1301-1308.

20. Noda Y, Yamada K, Furukawa H, Nabeshima T. Enhancement of immobility in a forced swimming test by subacute or repeated treatment with phencyclidine: a new model of schizophrenia. Br J Pharmacol 1995;116:2531-2537.

21. Noda Y, Kamei H, Mamiya T, Furukawa H, Nabeshima T. Repeated phencyclidine treatment induces negative symptomlike behavior in forced swimming test in mice: imbalance of prefrontal serotonergic and dopaminergic functions. Neuropsychopharmacology 2000;23:375-387.

22. Ahlander M, Misane I, Schött PA, Ogren SO. A behavioral analysis of the spatial learning deficit induced by the NMDA receptor antagonist $M K-801$ (dizocilpine) in the rat. Neuropsychopharmacology 1999;21:414-426.

23. Eyjolfsson EM, Brenner E, Kondziella D, Sonnewald U. Repeated injection of MK801: an animal model of schizophrenia? Neurochem Int 2006;48:541-546.

24. Zhu XJ, Hua Y, Jiang J, Zhou QG, Luo CX, Han X, et al. Neuronal nitric oxide synthase-derived nitric oxide inhibits neurogenesis in the adult dentate gyrus by down-regulating 
cyclic AMP response element binding protein phosphorylation. Neuroscience 2006;141:827-836.

25. Fumagalli F, Molteni R, Roceri M, Bedogni F, Santero R, Fossati $\mathrm{C}$, et al. Effect of antipsychotic drugs on brainderived neurotrophic factor expression under reduced $N$-methyl-D-aspartate receptor activity. $J$ Neurosci Res 2003;72:622-628.

26. Hou Y, Wu CF, Yang JY, Guo T. Differential effects of haloperidol, clozapine and olanzapine on learning and memory functions in mice. Prog Neuropsychopharmacol Biol Psychiatry 2006;30:1486-1495.

27. Kant GJ, Wright WL, Robinson TN 3rd, D'Angelo CP. Effects of MK-801 on learning and memory as assessed using a novel water maze. Pharmacol Biochem Behav 1991;39:479-485.

28. Zuo DY, Zhang YH, Cao Y, Wu CF, Tanaka M, Wu YL. Effect of acute and chronic MK-801 administration on extracellular glutamate and ascorbic acid release in the prefrontal cortex of freely moving mice on line with open-field behavior. Life Sci 2006;78:2172-2178.

29. Ahn KJ, Jeong HK, Choi HS, Ryoo SR, Kim YJ, Goo JS, et al. DYRK1A BAC transgenic mice show altered synaptic plasticity with learning and memory defects. Neurobiol Dis 2006;22:463-472.

30. Park SW, Kim YK, Lee JG, Kim SH, Kim JM, Yoon JS, et al. Antidepressant-like effects of the traditional Chinese medicine kami-shoyo-san in rats. Psychiatry Clin Neurosci 2007:61:401-406.

31. Parent JM, Yu TW, Leibowitz RT, Geschwind DH, Sloviter RS, Lowenstein DH. Dentate granule cell neurogenesis is increased by seizures and contributes to aberrant network reorganization in the adult rat hippocampus. J Neurosci 1997; 17:3727-3738.

32. Terry AV Jr, Hill WD, Parikh V, Evans DR, Waller JL, Mahadik SP. Differential effects of chronic haloperidol and olanzapine exposure on brain cholinergic markers and spatial learning in rats. Psychopharmacology (Berl) 2002; 164:360-368.

33. Terry AV Jr, Hill WD, Parikh V, Waller JL, Evans DR, Mahadik SP. Differential effects of haloperidol, risperidone, and clozapine exposure on cholinergic markers and spatial learning performance in rats. Neuropsychopharmacology 2003;28:300-309.

34. Terry AV Jr, Parikh V, Gearhart DA, Pillai A, Hohnadel E, Warner S, et al. Time-dependent effects of haloperidol and ziprasidone on nerve growth factor, cholinergic neurons, and spatial learning in rats. J Pharmacol Exp Ther 2006;318:709-724.

35. Mandillo S, Rinaldi A, Oliverio A, Mele A. Repeated administration of phencyclidine, amphetamine and MK-801 selectively impairs spatial learning in mice: a possible model of psychotomimetic drug-induced cognitive deficits. Behav Pharmacol 2003;14:533-544.

36. Zemanova A, Stankova A, Lobellova V, Svoboda J, Vales $\mathrm{K}$, Vlcek K, et al. Visuospatial working memory is impaired in an animal model of schizophrenia induced by acute
MK-801: an effect of pretraining. Pharmacol Biochem Behav 2013;106:117-123.

37. Willis CL, Ray DE. Antioxidants attenuate MK-801-induced cortical neurotoxicity in the rat. Neurotoxicology 2007; 28:161-167.

38. Maeda K, Sugino H, Hirose T, Kitagawa H, Nagai T, Mizoguchi $\mathrm{H}$, et al. Clozapine prevents a decrease in neurogenesis in mice repeatedly treated with phencyclidine. J Pharmacol Sci 2007;103:299-308.

39. Storozheva ZI, Solovieva OA, Proshin AT, Sherstnev VV. Delayed effects of NMDA receptor antagonist MK-801 on storage and reconsolidation of spatial memory in rats. Bull Exp Biol Med 2012;153:605-608.

40. Keilhoff G, Bernstein HG, Becker A, Grecksch G, Wolf G. Increased neurogenesis in a rat ketamine model of schizophrenia. Biol Psychiatry 2004;56:317-322.

41. Cameron HA, McEwen BS, Gould E. Regulation of adult neurogenesis by excitatory input and NMDA receptor activation in the dentate gyrus. J Neurosci 1995;15:4687-4692.

42. Dong C, Rovnaghi CR, Anand KJ. Ketamine alters the neurogenesis of rat cortical neural stem progenitor cells. Crit Care Med 2012;40:2407-2416.

43. Li N, Lee B, Liu RJ, Banasr M, Dwyer JM, Iwata M, et al. mTOR-dependent synapse formation underlies the rapid antidepressant effects of NMDA antagonists. Science 2010; 329:959-964.

44. Xu H, Chen Z, He J, Haimanot S, Li X, Dyck L, et al. Synergetic effects of quetiapine and venlafaxine in preventing the chronic restraint stress-induced decrease in cell proliferation and BDNF expression in rat hippocampus. Hippocampus 2006;16:551-559.

45. Green W, Patil P, Marsden CA, Bennett GW, Wigmore PM. Treatment with olanzapine increases cell proliferation in the subventricular zone and prefrontal cortex. Brain Res 2006; 1070:242-245.

46. Kodama M, Fujioka T, Duman RS. Chronic olanzapine or fluoxetine administration increases cell proliferation in hippocampus and prefrontal cortex of adult rat. Biol Psychiatry 2004:56:570-580.

47. Halim ND, Weickert CS, McClintock BW, Weinberger DR, Lipska BK. Effects of chronic haloperidol and clozapine treatment on neurogenesis in the adult rat hippocampus. Neuropsychopharmacology 2004;29:1063-1069.

48. Kim NR, Park SW, Lee JG, Kim YH. Protective effects of olanzapine and haloperidol on serum withdrawal-induced apoptosis in SH-SY5Y cells. Prog Neuropsychopharmacol Biol Psychiatry 2008;32:633-642.

49. Lee JG, Cho HY, Park SW, Seo MK, Kim YH. Effects of olanzapine on brain-derived neurotrophic factor gene promoter activity in SH-SY5Y neuroblastoma cells. Prog Neuropsychopharmacol Biol Psychiatry 2010;34:1001-1006.

50. Park SW, Phuong VT, Lee CH, Lee JG, Seo MK, Cho HY, et al. Effects of antipsychotic drugs on BDNF, GSK-3 $\beta$, and $\beta$-catenin expression in rats subjected to immobilization stress. Neurosci Res 2011;71:335-340. 